\title{
研究報告：
}

\section{一般病院における認知症ケアの 質向上のためのストラテジー立案}

\section{平川仁尚*}

認知症患者は，入院中にせん妄，徘徊，暴言・暴力など周辺症状を引き起こしやすいた め, 担当看護師の負担は大きい。今回，一般病院の認知症ケアの質の向上を目的に，その ストラテジーの立案を行なったので報告する。研究対象は, 江南厚生病院の副看護部長 2 名, 看護課長 1 名, 看護係長 3 名, 医療ソーシャルワーカー 2 名, 地域包括支援センター ソーシャルワーカー 1 名, 訪問看護ステーション看護課長 1 名, 院外のケアマネジャー 2 名であった。データ収集には，フォーカスグループインタビューを用いた。分析方法につ いて，意味の近似性に基づき，抽出されたラベルをサブカテゴリーとカテゴリーに分類し た。全カテゴリーについて，座標軸を用いて優先順位の決定を行なった。その最優先課題 について討論を行ない, 特性要因図で整理した。その結果, 認知症ケア専門チームの立ち 上げ，認知症ケアへの理解と共感の輪を院内の関係者に広げるための教育，啓発，研修が 必要であることが分かった。

\section{(1)認知症 (2)入院 (3)看護 (4)業務改善 (5)特性要因図}

\section{緒蓑}

認知症は精神的のみならず，身体的，社会的 にも健康障害を引き起こすため, 介護者の負担 は大きく，国の財政負担も大きい(1,2)。まさに， 認知症高齢者のケアは社会問題となっていると いえる。

一般病院においても, 認知症高齢者が身体疾 患で入院する機会が多いため, 認知症高齢者へ の対応が迫られている ${ }^{3,4)}$ 。認知症患者は，入院 中にせん妄, 徘徊, 暴言・暴力など周辺症状を 引き起こしやすいため, 担当看護師の負担は大 きい。

一般病院の認知症ケアに関する看護師の困難 に焦点を当てた先行研究は散見されるが3,4), 病

* \%466-8550 愛知県名古屋市昭和区鶴舞町65 名古屋大学大学院医学系研究科国際保健医療学・公衆衛 生学教室

(受付：2016年 9 月15日)
院全体として認知症ケアの業務改善に取り組ん だ報告はほとんどない。今回，一般病院の認知 症ケアの質の向上を目的に，そのストラテジー の立案を行なったので報告する。

\section{方法}

1. 研究対象 : 江南厚生病院の認知症に関わる 業務をしている副看護部長 1 名，地域連携に関 わる業務をしている副看護部長 1 名, 認知症患 者の対応を検討するチームに属する看護課長 1 名と看護係長 3 名, 医療ソーシャルワーカー 2 名, 地域包括支援センターソーシャルワーカー 1 名, 訪問看護ステーション看護課長 1 名, 院 外のケアマネジャー 2 名であった。

2. 研究期間 : 平成 28 年 3 月〜 8 月であった。

3.データ収集：フォーカスグループインタ ビューを用いた。対象者から出された意見は フィールドノートに記録した。後にアイデアの 一つひとつをラベルに記載した。インタビュー 
は概ね50分であった。

4. 分析方法：内容分析 ${ }^{5)}$ に準じて, 抽出され たラベルを意味単位（meaning unit）として テーマ分類した。信頼性の確保のため, 抽出さ れたラベルについては，対象者全員が内容の正 誤について確認を行なった。次に，全テーマに ついて，座標軸を用いて優先順位の決定を行 なった。その際, 横軸に問題解決の緊急度, 縦 軸に問題解決の重要度をとった。すなわち,

$\mathrm{XY}$ 平面上で最も右上に位置する問題が問題解 決の最優先課題である。最後に, その最優先課 題について，対象者は順番に 1 つずつアイデア を提示し，最低，全員が 2 回発言できるまで討 論を続けた。後日，そのアイデア一つひとつを 特性要因図 $\left.{ }^{6}\right)$ で整理した。

5. 倫理的配慮：本研究の実施に当たっては, 事前に名古屋大学大学院医学系研究科生命倫理 審査委員会の承認を得た（承認番号20150444)。

\section{結果}

フォーカスグループの内容から33枚の意味単 位が抽出された。それらを12のカテゴリー，9 のテーマに分類した（表 1 )。以下，抽象度の 高い順にテーマを【】，カテゴリーを《》 で示し，記述する。

\section{1.フォーカスグループインタビュー}

【本人の意向より家族の意向の優先】

認知症高齢者は，自分の気持ちや感情の表出 が困難である。そのため，代わりに家族に意見 や同意を求めがちで，その際に本人の意向を疎 かにしてしまうことがある。

【時間と余裕のなさ】

《家族は心に余裕がなく介護にストレスを感 じている》, 《看護師は認知症のことまで手が回 らず心を痛めている》のサブカテゴリーから， 家族や看護師は，心に余裕を持って，認知症高 齢者に接してあげたいと思っているができない ことで自責の念にかられていることが示唆され た。
【入院環境の問題】

入院を契機に認知症高齢者が混乱し, 周辺症 状が出現することは広く知られている。また,

《認知症患者の人が楽しくコミュニケーション できる場所が院内にあるといい》という対象者 の発言にもみられるように，院内には認知症高 齢者が安心して過ごせる場所は限られている。 対象者は，認知症高齢者に配慮した入院環境の 整備が契緊の課題と考えている。

【報酬の少なさ】

診療報酬により，病院が新たに認知症ケアに 携わる人員を確保したり，職員の研修費用に充 てたり，チームアプローチを推進したりする費 用を確保できるようになる。

【本人の受診拒否】

認知症は自覚症状がないため, 認知症患者は しばしば外来受診を拒否するし，自ら進んで受 診をすることもない。

\section{【受け入れ拒否】}

入院中，特に入院直後には，認知症患者は全 身状態の悪化や環境の変化により周辺症状 Behavioral and Psychological Symptoms of Dementia（BPSD）を呈することが多い。暴言, 暴力, 介護への抵抗などはしばしば転院や高齢 者介護施設入所を断られる原因となる。

\section{【日常生活の危機】}

認知症ケアにおいて, 医療, 介護, 福祉サー ビスが効率よく，効果的に統合されることが望 ましい。対象者は多職種で情報交換をすること が認知症患者に優しい地域を作るのに不可欠だ と考えていた。

【認知症ケア専門チーム】

認知症ケア専門チームは必ずしも全国に普及 していないが，対象者はこのチームの必要性を 強く認識していた。認知症ケア専門チームは, 神経内科医，老年内科医，看護師，ソーシャル ワーカーらを含めた多職種混成チームであるこ とが望ましく，投薬やケアの相談，スタッフや 家族への教育などが主な業務である。

【地域からの働きかけ】

一人暮らしの高齢者は社会から孤立しやす い。医師，看護師，ケアマネジャーは情報が少 
表 1。病院と地域の連携プレーで危機を乗り越える

\begin{tabular}{|c|c|c|}
\hline テーマ & カテゴリー & 意 味 単 位 \\
\hline $\begin{array}{l}\text { 本人より } \\
\text { 家族の意向 }\end{array}$ & & $\begin{array}{l}\text { 家族の思いや意向が優先され, 本人の意向が尊重されないケース } \\
\text { がある }\end{array}$ \\
\hline \multirow[t]{2}{*}{ 余裕のなさ } & $\begin{array}{l}\text { 家族は心に余裕がなく介 } \\
\text { る } \\
\text { る }\end{array}$ & $\begin{array}{l}\text { 家族は仕事も生活もギリギリなので認知症患者にイライラしてし } \\
\text { まうのだ思う } \\
\text { 家族は, 認知症であっても本人に対して配慮なく怒ってしまって } \\
\text { いる } \\
\text { 家族が献身的に尽くしても感謝を忘れてしまい, 家族が辛い思い } \\
\text { をしている }\end{array}$ \\
\hline & $\begin{array}{l}\text { 看護師は認知症のことま } \\
\text { で手が回らず心を痛めて } \\
\text { いる }\end{array}$ & $\begin{array}{l}\text { 拘束してまで認知症患者の治療をするのは本当に本人のためなの } \\
\text { かと悩む } \\
\text { カンファレンスはあるが看護師が認知症について話し合う機会は } \\
\text { 少ない } \\
\text { 重症患者が同じ病棟に居ると認知症患者に丁寧な対応をしている } \\
\text { 余裕がない } \\
\text { ゆっくりと話を聞く時間があれば本人や家族の困っていることや } \\
\text { 病状について詳しく知ることができるのにと思う } \\
\text { 食事提供の前や早朝, 夜間など人手が手薄になる時に限って問題 } \\
\text { 行動（周辺症状）が多い気がする }\end{array}$ \\
\hline $\begin{array}{l}\text { 安心の } \\
\text { 入院環境 }\end{array}$ & 今゙きる & $\begin{array}{l}\text { 入院環境は認知症の人の目線からは不安だらけだと思う } \\
\text { 認知症患者の人が楽しくコミュニケーションできる場所が院内に } \\
\text { あるといい }\end{array}$ \\
\hline $\begin{array}{l}\text { 低すぎる } \\
\text { 報酬 }\end{array}$ & $\begin{array}{l}\text { 認知症管理に関連した診 } \\
\text { 療報酬が低すぎる }\end{array}$ & $\begin{array}{l}\text { 認知症診療関連の診療報酬が上がるとよい } \\
\text { 現在の服薬システム（訪問薬剤管理月に } 2 \text { 回医療保険1回）では } \\
\text { 認知症患者の服薬管理が十分にできない }\end{array}$ \\
\hline 受診拒否 & $\begin{array}{l}\text { 本人の拒否により早期受 } \\
\text { 診が困難な場合がある }\end{array}$ & $\begin{array}{l}\text { 本人の拒否があり認知症の疑いがある人を受診させられない } \\
\text { 認知症の人を外来へ連れ出すのが大変なので専門医が往診してく } \\
\text { れたらと思う }\end{array}$ \\
\hline $\begin{array}{l}\text { 受け入れ } \\
\text { 拒否 }\end{array}$ & $\begin{array}{l}\text { 認知症の周辺症状は受け } \\
\text { 入れ拒否の原因となる }\end{array}$ & $\begin{array}{l}\text { 認知症の人は入院すると認知症状が現れるので困る } \\
\text { 管理上の問題を理由に認知症患者の療養先が制限されることがあ } \\
\text { る }\end{array}$ \\
\hline \multirow[t]{5}{*}{ 生活の危機 } & $\begin{array}{l}\text { 病院, 地域包括支援セン } \\
\text { ターサービス事業所のス } \\
\text { ムーズな橋渡しが必要だ }\end{array}$ & $\begin{array}{l}\text { 看護師が会話し認知症が疑わしいと分かった人を地域包括支援セ } \\
\text { ンター併設の病院の紹介すればサービス利用に繋げることができ } \\
\text { る } \\
\text { 病院やサービス事業所の抱え込みがあって困る }\end{array}$ \\
\hline & $\begin{array}{l}\text { 認知症の人の身の安全を } \\
\text { 地域で確保することは緊 } \\
\text { 急の課題である }\end{array}$ & $\begin{array}{l}\text { 認知症関連の列車事故, 車事故が多発しており, 本人や市民の命 } \\
\text { の危険がある } \\
\text { 徘徊しても居場所，身元の確認や安全確保ができるようにマイク } \\
\text { ロチップを身体に植込みができると良い }\end{array}$ \\
\hline & $\begin{array}{l}\text { 各科の医師はその人の生 } \\
\text { 活にも関心を持ってもら } \\
\text { いたい }\end{array}$ & $\begin{array}{l}\text { 医師同士の認知症関連情報の共有をしてほしい } \\
\text { 医師は患者の生活や社会背景に関心がない } \\
\text { 総合病院では認知症の人は各科で部分的に診られ1人の人として } \\
\text { 診てもらうことができない }\end{array}$ \\
\hline & & 学校や会社に認知症に関する教育を義務化してほしい \\
\hline & & 認知症の人は金銭管理ができなくなる \\
\hline
\end{tabular}


認知症専門 病院や病棟に認知症ケア 認知症専門ケアを習得した人が病棟に居てほしい

のチーム アドバイザーがいてほし 管理職は各職種間の認知症に関する理解度と教育の仕方がわから い ない

認知症の専門医が不足， 精神科医が週に 3 回しかいないので相談できる先生がもっといる 不在である といい

江南厚生病院にも老年科と精神科の常勤医師がいてほしい

地域の働き 家族介護者が不在だと情 認認介護や独居の場合, 認知症の問題は発見が遅れがちだ

かけ 報収集すらままならない 認知症患者が一人暮らしだと在宅での様子がよくわからないので 困る

家族は本人が認知症であることを周囲に隠したがる

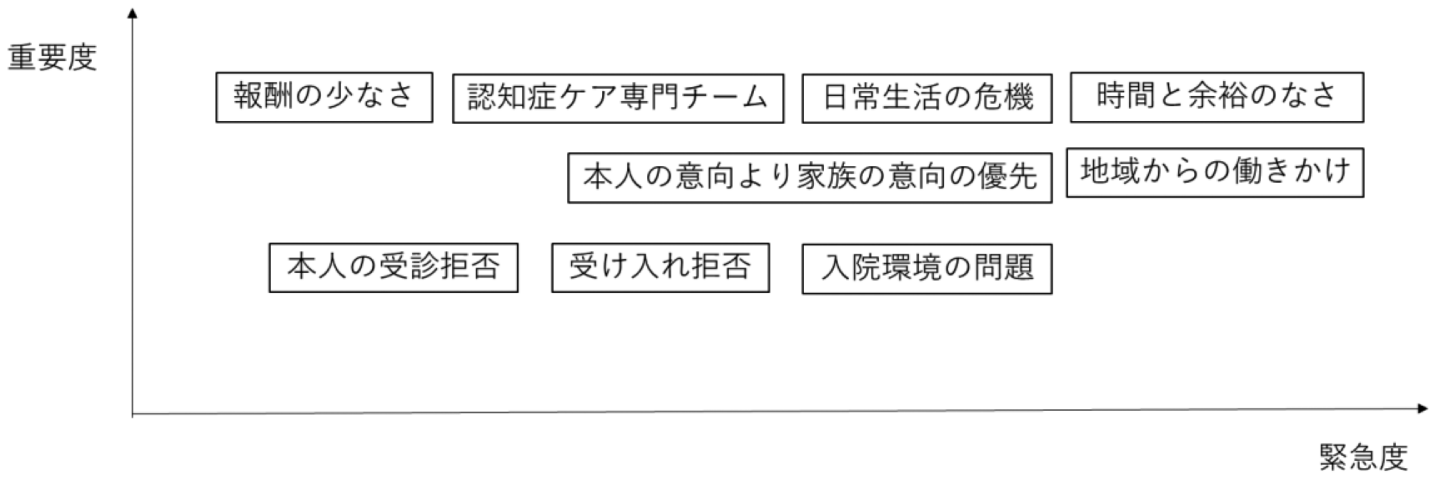

図 1。座標軸による優先順位付け

ない中で，地域の助けを借りて，未然に高齢者 の孤立や健康状態の悪化を防がなければならな い。

\section{2. 座標軸と特性要因図}

座標軸（図 1 ）により，【時間と余裕のなさ】 が最優先課題となった。討論で出されたアイデ アを反映させ，【時間と余裕のなさ】を特性と した特性要因図（図 2 ）を作成した。

\section{考察}

本研究の対象者は, 認知症ケア専門チームを 立ち上げたい，医師や看護師にもっと認知症に 理解や関心を持ってほしい, 地域の認知症ケア の質の向上のために地域と密に連携していきた いと感じていた。つまり，対象者は，認知症患 者本人に対する院内外の協働アプローチが地域 の認知症ケアの質の向上に寄与すると考えてい た。また，対象者は，家族や看護師のストレス を軽減するために，労いの言葉と共感が重要だ と認識していた。
認知症ケアにおいては, 多職種協働アプロー チが理想であるとされるが，実際は各専門職が 個別にケアを提供していることが多い7)。認知 症診療を専門としない医師の多くは, 認知症の 社会的側面まではあまり関心がない。今回の結 果でも, 認知症に理解を示す医師を切望する意 見がみられた。認知症ケア専門チームにより， 認知症診療に不慣れな医師や看護師のサポート が期待でき, 認知症ケアに必要な包括的評価を 効率的かつ効果的に行なうことも可能になると 期待される。

認知症ケアの質の向上のために，ケアに携わ る人への直接的な労いだけでなく，認知症ケア への理解と共感の輪をいかに関係者に広げるか が重要であることが分かった。本人からの感謝 の言葉を緅った手紙を家族に渡す，家族からの 良い評価をスタッフに伝えるなど具体的な提案 がみられた。同僚からの励まし（ピアサポー 卜）や上司からの労いの言葉なども提案され た。病院全体からの評価として良い認知症対応 したスタッフを表彰する制度の提案もあった。 


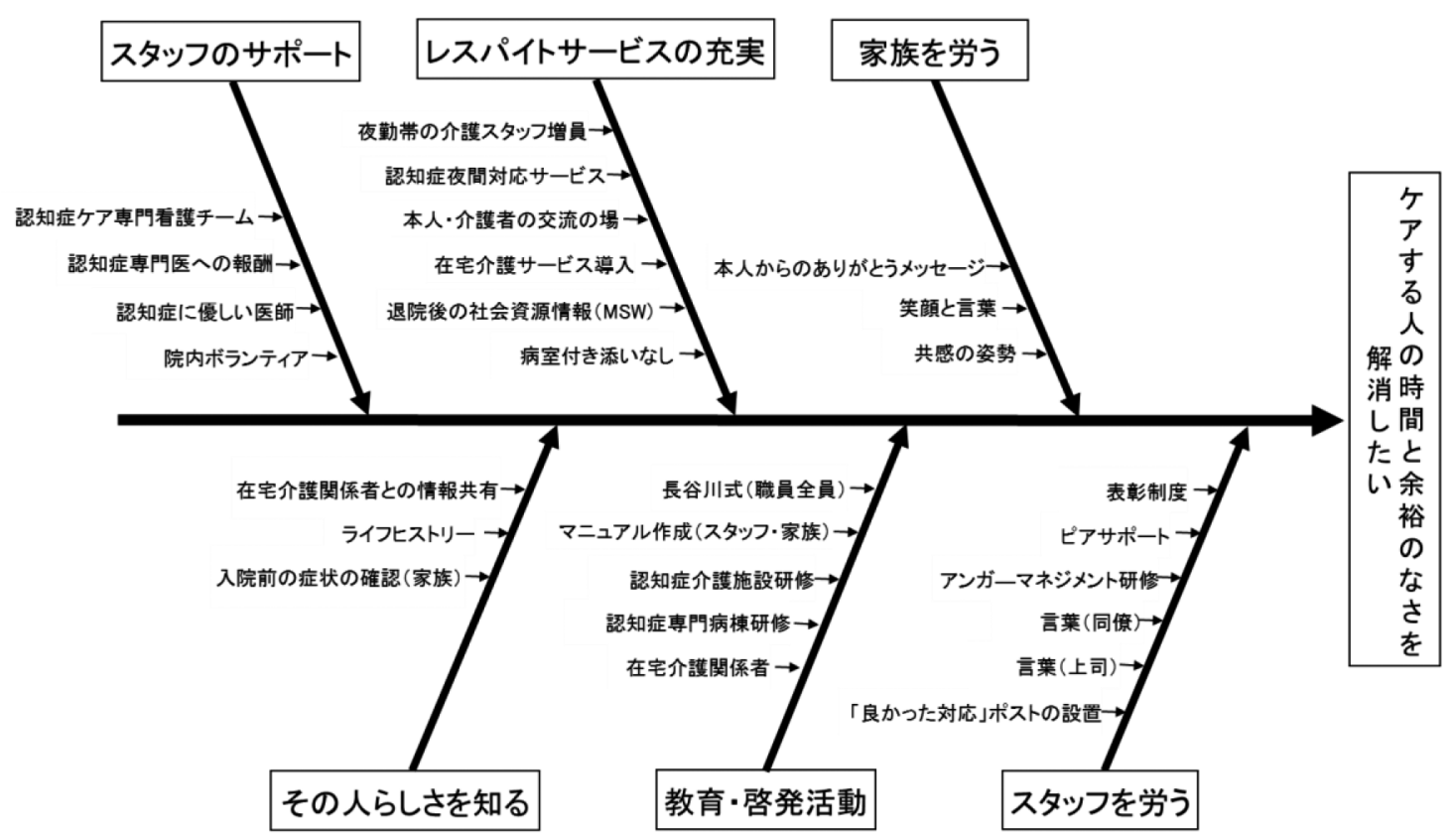

図 2. 特性要因図

注：長谷川式一長谷川式簡易知能評価スケール, MSW一医療ソーシャルワーカー

認知症の介護は感情のケアといわれ，同じこと を何回も聞かれたり，介護に抵抗を示された り，ストレスや怒りが溜まりやすい8,9)。アン ガーマネジメント（怒りのマネジメント）研 修9)の必要性が示唆されたように，いかに心的 ストレスを軽減するか重要である。

スタッフや家族への教育も重要である。認知 症への上手な対応をマニュアル化する，スタッ フが認知症ケアの現場を見学・体験する, 職員 全員が認知機能評価スケールを体験する，認知 症ケアの経験が豊富な在宅介護関係者を講師と して招聘することが提案された。認知症ケアの 理論よりも具体的な対応法を学習したいという 対象者のニーズが明らかとなった。

院内ボランティアの活用も提案された。認知 症の人との接し方について学んだ地域のボラン ティアに，看護師やその他の職員と協力して, 認知症患者に少しでも安心できる環境を整えて もらえることを対象者は期待していた。

\section{結 論}

今回, 医療・福祉職が一堂に会して討論した 結果, グループダイナミクスにより病院全体と
して取り組む課題が明らかとなった。ストラテ ジー立案も試みた結果, 認知症ケア専門チーム の立ち上げ，認知症ケアへの理解と共感の輪を 院内の関係者に広げるための教育, 啓発, 研修 が必要であることが示唆された。

$$
\text { 謝辞 }
$$

本研究にご協力いただいた JA 愛知厚生連江南厚生 病院の関係者に謝意を表す。

\section{著者のCOI 開示}

本論文発表内容に関連して特に申告なし。

$$
\text { 文献 }
$$

1 ) Maki Y, Yamaguchi H. Early detection of dementia in the community under a communitybased integrated care system. Geriatr Gerontol Int. $2014 ; 14$ (Supple 2) : $2-10$.

2 ) Awata S, Sugiyama M, Ito K, et al. Development of the dementia assessment sheet for community-based integrated care system. Geriatr Gerontol Int. 2016 ; 16(Suppl 1) : 123-131.

3 ）天木伸子, 百瀬由美子, 松岡広子. 一般病院で入 院治療する認知症高齢者への看護実践に扔ける認 知症看護認定看護師の判断. 日本看護研究学会雑 誌 $2014 ； 37(4) ： 63-72$. 
4）千田睦美，水野敏子．認知症高齢者を看護する看 護師が感じる困難の分析．岩手県立大学看護学部 紀要 $2014 ; 16: 11-16$.

5 ) Graneheim UH, Lundman B. Qualitative content analysis in nursing research: concepts, procedures and measures to achieve trustworthiness. Nurse Educ Today 2004 ; 24(2) : 105-112.

6 ) Chang H. Evaluation Framework for Telemedicine Using the Logical Framework Approach and a Fishbone Diagram. Healthe Inform Res. $2015 ; 21(4): 230-238$.
7 ) Galvin JE, Valois L, Zweig Y. Collaborative transdisciplinary team approach for dementia care. Neurodegener Dis Manag. 2014 ; 4(6) : 455 -469 .

8 ）柴田由己, 安部幸志, 新井明日奈, 他. 一般生活 者を対象とした認知症家族の介護に対する感情尺 度の作成。日本老年医学会雑誌 $2010 ； 47(4)$ : $315-322$.

9 ）平川仁尚. 介護関係者を対象にしたアンガーマネ ジメントワークショップの開催. 日本農村医学会 雑誌 $2014 ； 63(2) ： 151-153$.

\title{
Creating a Strategy for Improving Dementia Care in a General Hospital
}

\author{
Yoshihisa HIRAKAWA*
}

Inpatients with dementia are prone to delirium and aimless wandering, and they often become verbally and physically abusive. Thus, caring for these patients places considerable burden on nurses. This article reports on the creation of a strategy for dementia care in a general hospital. Subjects were staff of Konan Kosei Hospital - 2 deputy chief nurses, 1 section chief nurse, 3 unit chief nurses, 2 medical social workers, 1 integrated community support social worker, and 1 section chief nurse (home-visiting division) - and 2 independent care managers. Focus group interviews were conducted to collect data, and extracted labels were classified into subcategories and categories according to similarity in meaning. A two-dimensional development method was used to prioritize tasks in each category. The highest priority tasks were discussed and sorted using characteristic diagrams. It is necessary for a new team dedicated to dementia care to be created and for education, enlightenment, and training to be provided so as to increase understanding of dementia care and empathy among a wider range of professionals working in the hospital.

\footnotetext{
* Dept. of Public Health and Health Systems, Nagoya University Graduate School of Medicine, Aichi, Japan
} 